\title{
ANTIEPILEPTIC DRUGS' TOLERABILITY AND SAFETY - A SYSTEMATIC REVIEW AND META-ANALYSIS OF ADVERSE EFFECTS IN DOGS
}

\author{
Charalambous $\mathrm{M}^{1}$, Shivapour $\mathrm{SK}^{2}$, Brodbelt $\mathrm{D}^{3}$, Volk HA ${ }^{3}$ \\ ${ }^{1}$ University College London, UK, ${ }^{2}$ Iowa State University, Ames, USA and ${ }^{3}$ Royal Veterinary College, London, UK
}

\section{Background}

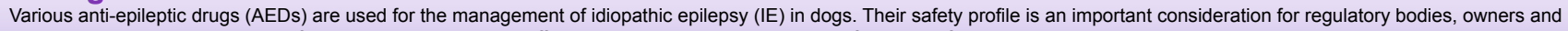

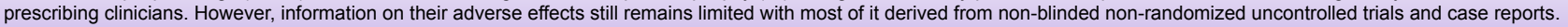

\section{Aim of the study}

This is the first systematic review and meta-analysis in veterinary medicine which evaluates studies that describe the safety profile of AEDs used for the management of IE in dogs, based on objective criteria.

\section{Material \& Methods}

$\checkmark$ Electronic searches of PubMed, Google Scholar and CAB Direct were carried out (03 January 2016) without date or language restrictions. Proceedings of ECVN/ACVIM annual congresses were searched. Peer-reviewed full-length studies describing objectively the adverse effects of AEDs in dogs with IE were included.

$\checkmark$ Studies were selected based on specific inclusion criteria and a two-stage screening process. Final studies were evaluated on the grounds of their overall quality of evidence (figure1) as well as outcomes measures (table 1).

\section{Table 1: Criteria for evaluation of AEDs' safety profile}

\begin{tabular}{|c|c|c|c|}
\hline $\begin{array}{l}\text { Proportion of } \\
\text { specific adverse } \\
\text { effects for each } \\
\text { AED }\end{array}$ & $\begin{array}{l}\text { Prevalence and } 95 \\
\% \text { confidence } \\
\text { interval of the } \\
\text { affected } \\
\text { population in each } \\
\text { study }\end{array}$ & Comparative odds ratio of adverse effects for AEDs & $\begin{array}{l}\text { Level of evidence provided for } \\
\text { the safety profile of } \\
\text { each AED }\end{array}$ \\
\hline $\begin{array}{l}\text { Calculated for } \\
\text { each AED by } \\
\text { dividing the } \\
\text { number of studies } \\
\text { that reported a } \\
\text { specific adverse } \\
\text { effect by the total } \\
\text { number of the } \\
\text { studies for this } \\
\text { AED. }\end{array}$ & $\begin{array}{l}\text { Calculated for each } \\
\text { study by dividing } \\
\text { the number of } \\
\text { subjects that } \\
\text { developed adverse } \\
\text { effects during the } \\
\text { specified study } \\
\text { period by the total } \\
\text { size of the study } \\
\text { population. }\end{array}$ & $\begin{array}{l}\text { The odds ratio (OR) was estimated in order to } \\
\text { indicate the increased or decreased odds of observing } \\
\text { specific adverse effect(s) in total for an AED compared } \\
\text { to its control group (comparison AED or placebo or } \\
\text { untreated animals). The OR for dichotomous data was } \\
\text { calculated using the random-effects model in Review } \\
\text { Manager } 5.3 \text {. Associations were considered to be } \\
\text { statistically significant at } P<\mathbf{0 . 0 5} \text {. }\end{array}$ & $\begin{array}{l}\text { 'Strong ' evidence was } \\
\text { provided for the safety profile } \\
\text { when at least one bRCT } \\
\text { reported or assessed the } \\
\text { adverse effects of an AED; } \\
\text { 'Weak' evidence was provided } \\
\text { for the safety profile when } \\
\text { bRCTs were not available. }\end{array}$ \\
\hline
\end{tabular}

bRCT(s); blinded randomized clinical trial(s)
Figure 1: Criteria for evaluation of the overall quality of evidence for each study

Blinded randomized clinical trials (bRCTs) with large group sizes, clear inclusion criteria and diagnostic investigations that included clinical signs and thorough test results consistent with the diagnosis of $\mathrm{IE}$, describing outcomes specific for IE and low overall risk of bias were considered to provide the highest available quality of evidence.

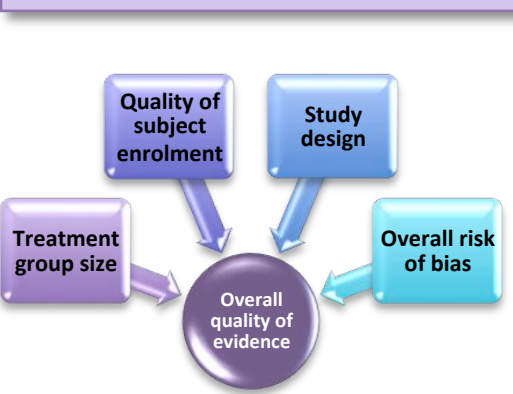

\section{Results}

\section{Table 2: Level of evidence for AEDs' safety profile}

\begin{tabular}{|c|c|c|c|}
\hline \multirow{2}{*}{$\begin{array}{l}\text { Overall } \\
\text { number of } \\
\text { studies } \\
\text { detected }\end{array}$} & \multirow{2}{*}{$\begin{array}{l}\text { Total number of } \\
\text { studies evaluated } \\
\text { after the two-stage } \\
\text { screening process }\end{array}$} & \multirow{2}{*}{$\begin{array}{l}\text { Number of } \\
\text { studies with the } \\
\text { highest overall } \\
\text { quality of } \\
\text { evidence }\end{array}$} & Level of evidence provided for each AED safety profile \\
\hline & & & Strong \\
\hline
\end{tabular}

$$
\text { detected screening process evidence }
$$

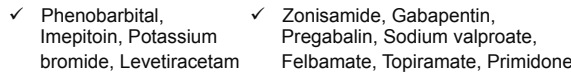

\section{Figure 3: Staircase of AED's safety profile hierarchy}

Direct comparisons suggested that imepitoin and levetiracetam might have a better safety profile than phenobarbital, whilst the latter might have a better safety profile than potassium bromide. However, none of these comparisons showed a statistically significant difference. Comparisons between other AEDs were not possible due to lack of relative comparison studies. Individual AED assessments indicated that levetiracetam might be one of the safest AEDs, followed by imepitoin and then phenobarbital and potassium bromide. The safety profile in other AEDs was variable.

Potassium

bromide

\section{Figure 2: Risk of bias}

Risk of bias assessment presented as percentages across all included studies based on Cochrane and Syrcle's 'risk of bias' assessment tool. Overall high risk of bias in $>90 \%$ of the studies.

Random sequence generation (selection bias) Allocation concealment (selection bias) Blinding of participants and personnel (performance bias) Blinding of outcome assessment (detection bias) Incomplete outcome data (attrition bias) Selective reporting (reporting bias) Other bias

Low risk of bias $\square$ Unclear risk of bias \begin{tabular}{lllll}
\hline $0 \%$ & $25 \%$ & $50 \%$ & $75 \%$ & $100 \%$ \\
\hline
\end{tabular} High risk of bias

\section{Conclusions \& Discussion}

Adverse effects usually appeared mild in all AEDs and subsided once doses and/or serum levels were monitored or after the AED was withdrawn.

Although phenobarbital might be less safe than imepitoin and levetiracetam, there was insufficient evidence to classify it as an AED with a high risk of major adverse effects.

It is important for clinicians to evaluate both AEDs' effectiveness and safety on an individual basis before the selection of the appropriate monotherapy or adjunctive AED therapy. 